\title{
Digitálne platformy: sút’ažné právo verzus regulácia ex ante
}

\author{
Kalesná, K., Patakyová, M. T.* \\ KALESNÁ, K., PATAKYOVÁ, M. T.: Digitálne platformy: sútažné právo verzus \\ regulácia ex ante. Právny obzor, 104, 2021, č. 1, s. 26 - 38.

\begin{abstract}
Digital Platforms: Competition Law Versus Ex Ante Regulation. Digital age has brought many challenges for legal regulation. One of vividly discussed issue is a question on possible regulation of digital platforms. Digital platforms have had an impact within business sphere as well as broader socio-political impact. This article aspires to contribute to the discussion on regulation of digital platform, in particular it explores application of competition law and regulation ex ante. It asks to what extent can competition law solve issues related with digital platforms. Since an exhaustive answer to the question is beyond the limits of one article, this article focuses on the definition of a digital platform, followed by a discourse on competition law and ex ante regulation. The possible insufficiencies of competition law are examined based on two cases: German Facebook case and Google Shopping case. The article shows that competition law might be reaching its limits in
\end{abstract} \\ dealing with certain particular issues related to digital platforms.
}

Key words: digital platforms, competition law, ex ante regulation, Facebook, Google Shopping

\section{1 ÚVOD}

Súčasné obdobie digitalizácie vytvára nový priestor na realizáciu podnikatel'ských aktivít na nových špecifických trhoch, spravidla charakterizovaných dynamickou inováciou a technologickými zmenami. Je nepochybné, že existencia a rozvoj podnikania na báze internetu prináša aj nové formy porušovania pravidiel hospodárskej sút’aže a vo všeobecnosti vytvára pre právo - nielen sút'ažné - nové výzvy. Nejde pritom len o bezprostredné sút’ažné riziká internetového obchodu vrátane plošného zákazu predaja na internete či iné obmedzenia tohto predaja (napr. geo-blocking), ale aj o súvisiace okruhy problémov ochrany osobných údajov, ochrany spotrebitel'a a pod. ${ }^{11}$ Osobitný problém stojaci v centre pozornosti sútažných orgánov, najmä Európskej komisie (d’alej EK), predstavuje zneužívanie trhovej sily nových digitálnych platforiem. Digitálne platformy sa stávajú aj predmetom posudzovania regulačných orgánov ${ }^{2}$ atd'.

Doc. JUDr. Katarína K a 1 e s n á, CSc., Ústav európskeho práva, Právnická fakulta, Univerzita Komenského v Bratislave; participovala na tomto článku v rámci grantu APVV-17-0641: Zeefektívnenie právnej úpravy verejného obstarávania a jej aplikácie v kontexte práva Európskej únie.

JUDr. Mária T. P a t a k y o v á, PhD., Ústav európskeho práva, Právnická fakulta, Univerzita Komenského v Bratislave; participovala na tomto článku v rámci projektu Jean Monnet Network Project 611293-EPP-12019-1-CZ-EPPJMO-NETWORK European Union and the Challenges of Modern Society.

${ }^{1}$ Bližšie pozri KASENČÁKOVÁ, L. Internet ako priestor porušovania pravidiel hospodárskej sút’aže. In Zborník príspevkov z medzinárodnej vedeckej konferencie 21. - 22. októbra 2016, Internet ako priestor možného porušovania práv, Bratislavské právnické fórum 2016. Bratislava : Univerzita Komenského v Bratislave, Právnická fakulta, 2016, s. 58 - 68.

${ }^{2}$ Tamže, s. 65 . 


\section{DIGITÁLNA PLATFORMA}

\subsection{Pojem}

Hoci ide o jednu z klúčcových otázok spätých s procesom digitalizácie ekonomiky, presná definícia digitálnej platformy je doposial' sporná. ${ }^{3} \mathrm{~V}$ odbornej literatúre sa možno stretnút's rôznymi definíciami digitálnych platforiem. L. Kasenčáková s odvolaním na pramene EK vníma online platformy ako „dvojstranné alebo viacstranné trhy, kde sa stretávajú uživatelia a prevádzkovatelia platformy s ciel'om ul'ahčit' vzájomnú interakciu ako napr. výmenu informácii alebo obchodnú transakciu. Medzi užívatel'ov pritom môžu patrit' rôzne skupiny od odberatel'ov, predajcov, inzerentov, vývojárov softvéru a podobne. Medzi online platformy možno zaradit' napr. Amazon, Marketplace, Bing Search, Facebook, Google Play, Google Search, Uber a d'alšie. "“4 Iná definícia digitálnych platforiem vyzdvihuje ich charakteristické znaky; „digitálne platformy zahŕňajú nástroje umožnené technológiou, ktorá ul’ahčuje výmeny medzi rôznymi skupinami napríklad konečnými uživatelmi a výrobcami - ktorí sa navzájom nemusia ani poznat." "5

Aj pri absencii univerzálnej definície je však potrebné odlíšit’ pravú „zdiel’anú ekonomiku“, ponúkajúcu výmeny na lokálnej úrovni, od ziskovo orientovaného globálneho obchodu, tzv. uberizácie ekonomiky ${ }^{6}$, pod ktorou sa rozumie „deštrukcia hodnotového ret'azca novými sprostredkovatel'mi, ktorí vd'aka použitiu digitálnych technológií (najmä aplikácií, smartfónov a online platobných systémov) získavajú čast' hodnoty na ujmu tradičných operátorov".?

Digitálne platformy, najmä ak pôsobia na hrane zákona, prinášajú nielen nové impulzy pre právnu reguláciu, ale aj mnohé právne spory, ako napr. Uber. ${ }^{8}$ Podl'a EK ${ }^{9}$,platformy dokázali, že sú inovátormi v digitálnej ekonómii a že pomáhajú menšiemu podnikaniu napredovat' online a dosiahnut nové trhy. Nové platformy v službách mobility, turizmu, hudby, audiovízie, vzdelania, financií, ubytovania a náboru sú rýchlou a hlbokou výzvou pre tradičné obchodné modely a rástli exponenciálne. Vzrast zdiel'anej ekonómie ponúka aj možnosti zvýšenej efektívnosti, rastu a pracovných miest, prostredníctvom lepšieho výberu spotrebitel’a, ale zároven potenciálne kladie nové regulačné otázky. " ${ }^{10}$

${ }^{3}$ JONES, A. - SUFRIN, B. EU Competition Law. 6th edition. Oxford : Oxford University Press, 2016, s. 49.

${ }^{4}$ KASENČÁKOVÁ, L. Internet ako priestor porušovania pravidiel hospodárskej sút'aže, cit. dielo, s. 65.

${ }^{5}$ GERADIN, D. What should EU competition policy do to address the concerns raised by the Digital Plarforms' market power? s. 1, [online], 2018, [cit. 28. 09. 2020]. Dostupné na internete: https://papers.ssrn. $\mathrm{com} /$ sol3/papers.cfm?abstract_id=3257967.

${ }^{6}$ STROWEL, A. - VERGOTE, W. Digital Platforms: To Regulate or Not To Regulate?, s.2, [online], [cit. 28. 09. 2020]. Dostupné na internete: https://ec.europa.eu/information_society/newsroom/image/document/2016-7/ uclouvain_et_universit_saint_louis_14044.pdf.

${ }^{7}$ Tamže.

${ }^{8}$ Tamže, s. 1 .

${ }^{9}$ Communication, A Digital Single Market Strategy for Europe, COM(2015), 192 final, 6 May 2015.

${ }^{10}$ Tamže. 


\subsection{Typológia digitálnych platforiem}

Kategorizácia digitálnych platforiem vychádza zo zohl'adnenia rôznych kritérií; $\mathrm{v}$ tomto zmysle možno hovorit’ napr. o dvojstranných a viacstranných platformách, ale aj o transakčných a netransakčných trhoch. Podl'a Jones a Sufrin ,na transakčnom trhu platforma spája uživatel’ov z každej strany a umožňuje im vstúpit’ do vzájomných transakcii. " 11 Ako príklad uvádzajú Airbnb, platobné karty a pod. ${ }^{12}$ Naproti tomu pri netransakčných trhoch k transakcii nedochádza; príkladom sú sociálne siete. ${ }^{13}$

Strowel a Vergote zakladajú typológiu digitálnych platforiem na základe zdrojov, ku ktorým umožňujú:

a) prístup $\mathrm{k}$ informáciám;

b) prístup k osobným údajom a inému súkromnému obsahu;

c) prístup k tovarom a službám;

d) prístup k pracovnej sile;

e) prístup k peniazom alebo ku kapitálu. ${ }^{14}$

\section{SÚŤAŽNÉ VÝZVY}

\subsection{Sút’až na digitálnom trhu}

Vzhl'adom na rozdielnost' obsahu i prudký rast významu digitálnych platforiem, spoločnosti stojace za nimi majú spravidla trhovú silu na jednom alebo viacerých základných trhoch, čím vytvárajú rôzne antitrustové výzvy. ${ }^{15}$ Je pritom zrejmé, že digitálne trhy modifikujú aj podmienky, za ktorých sút'až prebieha. So zretel'om na charakteristiku digitálnych trhov a s nimi spojené úspory z rozsahu, úlohu dát a sietové efekty/ externality ${ }^{16}$ Sufrin a Jones uvádzajú, že tradičná sút’až na trhu, ktorej základným parametrom býva cena, sa mení na sút'až o trh. ${ }^{17}$ I napriek existencii názoru, že digitálne trhy nevyžadujú antitrustovú intervenciu, lebo technologická inovácia znemožňuje udržat' si dlhodobejšie pozíciu trhovej sily ${ }^{18}$, EK sa nevzdáva vynucovania sút’ažného práva ani na digitálnych trhoch. ${ }^{19}$ Hoci modifikované podmienky sút'aže na týchto trhoch zrejme vyžadujú nový prístup k aplikácii sút’ažných pravidiel (napr. definícia

\footnotetext{
${ }^{11}$ JONES, A. - SUFRIN, B. EU Competition Law, cit. dielo, s. 49.

${ }^{12}$ Tamže.

${ }^{13}$ Tamže.

${ }^{14}$ STROWEL, A. - VERGOTE, W. Digital Platforms: To Regulate or Not To Regulate?, cit. dielo, s. 5.

${ }^{15}$ GERADIN, D. What should EU competition policy do to address the concerns raised by Digital Platforms market power?, cit. dielo, s. 2.

${ }^{16}$ CRÉMER, J. - De MONTJOYE, Y.-A. - SCHWEITZER, H. Competition Policy for the Digital Era, Final report, Executive Summary. Luxembourg : Publications Office of the European Union, 2019, [online], [cit. 28. 09. 2020]. Dostupné na internete: https://ec.europa.eu/competition/publications/reports/kd0419345enn.

${ }^{17}$ JONES, A. - SUFRIN, B. EU Competition Law, cit. dielo, s. 49.

${ }^{18}$ Tamže, s. $49-50$.

${ }^{19}$ Tamže, s. 50.
} pdf, s. 2. 
relevantného trhu a pod.), podl'a názoru EK nevyžadujú zmenu základnej právnej úpravy v Zmluve o fungovaní EÚ. ${ }^{20}$

\subsection{Sút’až v. regulácia}

Osobitným problémom, ktorý prináša digitalizácia ekonomiky, je vzájomný vzt’ah medzi sút’ažným právom a reguláciou. Podl'a autorov správy o sút’ažnej politike v digitálnej ére ${ }^{21}$ niet jednoznačnej odpovede na otázku, či je na riešenie problémov vyvolaných digitalizáciou ekonomiky vhodnejšie sút'ažné právo alebo regulácia ${ }^{22}$; podl'a ich názoru sa sút'ažné právo ako intervencia ex post a regulácia ako intervencia ex ante môžu vhodne doplńnat' na báze využitia synergického pôsobenia. ${ }^{23}$ Vo všeobecnosti možno konštatovat', že v niektorých oblastiach, ako sú napr. prirodzené monopoly, bude mat' v dôsledku absencie sút'ažného prostredia prioritný význam regulácia ex ante. Do určitej miery predstavuje takýto osobitný systém aj verejné obstarávanie, kde regulácia vyplýva z potreby simulácie konkurenčných tlakov v prípadoch, ked' nakupuje určité komodity verejný sektor. Zároveň treba pripomenút', že určité samoregulačné úsilie na digitálnych trhoch vytvárajú aj samy platformy. ${ }^{24}$

Treba korektne podotknút', že aj názory na potrebu regulácie sa môžu líšit'. Po regulácii ex ante volajú napr. operátori telekomunikačných služieb (Telekom), ktorí sami podliehajú takejto regulácii a ktorých infraštruktúru využívajú na prevádzku nových služieb a generovanie hodnoty globálni hráči ako Google, Facebook a pod. ${ }^{25}$ Problémom však zostáva, že kým telekomunikační operátori podliehajú národnej regulácii, globálni hráči prekračujú úroveň národných trhov. ${ }^{26}$

Všeobecnost’ právnej úpravy, právo generálnych klauzúl umožňuje v mnohých aspektoch sút’ažnému právu reguláciu digitálneho trhu ex post. K jeho výhodám patrí aj orgán ochrany sút'aže na úrovni EÚ, ako aj spolupráca sút’ažných orgánov členských štátov EÚ v rámci Európskej sút’ǎnej siete a efektívnost' sankčného postihu, ktorým disponujú. ${ }^{27}$ Treba však zdôraznit', že sama inštitucionálna výbava, samo vytvorenie nových regulačných orgánov na úrovni EÚ, nie sú dostačujúce. ${ }^{28} \mathrm{Na}$ riešenie všetkých legislatívnych impulzov, ktoré prinášajú digitálne platformy, rovnako zrejme nebude stačit' ani sút'ažné právo. ${ }^{29} \mathrm{~V}$ tomto zmysle slova budú zrejme potrebné aj adekvátne reakcie pracovného práva, daňového práva, práva intelektuálneho vlastníctva (napr. copyright), práva ochrany súkromia a pod. ${ }^{30}$

${ }^{20}$ CRÉMER, J. - De MONTJOYE, Y.-A. - SCHWEITZER, H. Competition Policy for the Digital Era, Final report, Executive Summary, cit. dielo, s. 3.

${ }^{21}$ CRÉMER, J. - De MONTJOYE, Y.-A. - SCHWEITZER, H. Competition Policy for the Digital Era, Final report, Executive Summary, cit. dielo.

${ }^{22}$ Tamže, s. 4.

${ }^{23}$ Tamže, s. 5.

${ }^{24}$ Tamže, s. 5.

${ }^{25}$ STROWEL, A. - VERGOTE, W. Digital Platforms: To Regulate or Not To Regulate?, cit. dielo, s. 11.

${ }^{26}$ Tamže.

${ }^{27}$ Tamže, s. 11.

${ }^{28}$ Tamže, s. 10.

${ }^{29}$ Tamže, s. 11.

${ }^{30}$ Tamže. 
Vychádzajúc z recentnej rozhodovacej praxe možno konštatovat', že cestou využitia prostriedkov sút'ažného práva sa vydala aj EK. EK sa sústredila najmä na otázku zneužitia dominantného postavenia digitálnych platforiem, najmä na otázku možného uzavretia trhu. Nejde však o jedinú oblast', ktorá vzbudzuje sút’ažné obavy; G. Damien osobitne zdôrazňuje nebezpečenstvo využitia vykorist'ovatel'ských praktík i správania smerujúceho k potláčaniu inovácií. Vykorist'ovatel'ské praktiky podl'a jeho názoru oproti tradičnej forme excesívnych cien ${ }^{31}$ prichádzajú skôr do úvahy v tom, že platforma poskytuje menej (napr. pokial' ide o kvalitu služby) a žiada viac (napr. dáta). ${ }^{32}$ Zo sút'ažného hl'adiska je vel'mi nebezpečné aj potláčanie inovácií, ktoré sa stávajú rozhodujúcim parametrom sút'aže digitálnych platforiem; ,sútaž je založená na inováciách, $t$. j. incumbentov môže prípadne nahradit' inovatívnejšia firma " ${ }^{33} \mathrm{Na}$ druhej strane, zhromaždenie vel'kého množstva informácií umožňuje globálnym hráčom (napr. Google) predvídat' na základe znalostí trhových trendov odkial' môžu príst' nové sút'ažné výzvy. ${ }^{34}$

Pre úplnost' je potrebné uviest', že Komisia pristúpila aj k regulácii vzt'ahov, do ktorých vstupujú platformy. Od júla 2020 platí v Európskej únii nariadenie Európskeho parlamentu a Rady (EÚ) 2019/1150 z 20. júna 2019 o podpore spravodlivosti a transparentnosti pre komerčných používatel'ov online sprostredkovatel'ských služieb. Účel nariadenia je vymedzený ako prispenie $\mathrm{k}$,riadnemu fungovaniu vnútorného trhu stanovením pravidiel na zabezpečenie toho, aby komerčným použivatel'om online sprostredkovatel'ských služieb a použivatel'om firemných webových stránok vo vzt'ahu k internetovým vyhl'adávačom bola poskytnutá primeraná transparentnost', spravodlivost' a možnosti účinnej nápravy“. Ide teda o reguláciu obchodných praktík medzi platformami a komerčnými používatel’mi (P2B) a webovými prehliadačmi a firemnými webovými stránkami.

Komerčný používatel' je definovaný ako ,akákol'vek súkromná osoba konajúca v rámci svojej obchodnej alebo odbornej činnosti alebo akákol'vek právnická osoba, ktorá prostredníctvom online sprostredkovatel'ských služieb ponúka tovar alebo služby spotrebitel'om na účely súvisiace s jej obchodom, podnikaním, remeslom alebo profesiou “35. Online sprostredkovatel'ská služba je charakterizovaná ako služba:

- informačnej spoločnosti ${ }^{36}$;

${ }^{31}$ Služby poskytované uživatel'om platforiem sú bezplatné.

${ }^{32}$ GERADIN, D. What should EU competition policy do to address the concerns raised by Digital Platforms market power?, cit. dielo, s. 6. Podl'a neho niektoré aspekty vykorist'ovania možno riešit' reguláciou. V tejto súvislosti uvádza aj Nariadenie EÚ o podpore spravodlivosti a transparentnosti pre komerčných používatel'ov online sprostredkovatel'ských služieb. (Autor cituje návrh nariadenia, v súčasnosti sa toto nariadenie uplatňuje od 12. 07. 2020.) Ciel'om tohto nariadenia je vytvorit' predvídatel'né regulačné prostredie pre online platformy v EÚ.

${ }^{33}$ Tamže.

${ }^{34}$ Tamže.

${ }^{35}$ Článok 2 ods. 1 nariadenia Európskeho parlamentu a Rady (EÚ) 2019/1150 z 20. júna 2019 o podpore spravodlivosti a transparentnosti pre komerčných používatel'ov online sprostredkovatel'ských služieb.

${ }^{36}$ Článok 1 ods. 1 písm. b) smernice Európskeho parlamentu a Rady (EÚ) 2015/1535 z 9. septembra 2015, ktorou sa stanovuje postup pri poskytovaní informácií v oblasti technických predpisov a pravidiel vzt’ahujúcich sa na služby informačnej spoločnosti. 
- ktorá umožňuje komerčným používatel'om ponúkat' tovar alebo služby spotrebitel'om s ciel'om ul'ahčit' začatie priamych transakcií medzi uvedenými komerčnými používatel'mi a spotrebitel'mi bez ohl'adu na to, kde sa uvedené transakcie nakoniec uzavrú;

- ktorá sa poskytuje komerčným používatel'om na základe zmluvných vzt'ahov medzi poskytovatel’om uvedených služieb a komerčnými používatel'mi, ktorí spotrebitel'om ponúkajú tovar alebo služby. ${ }^{37}$

Zjednodušene povedané, nariadenie sa sústred'uje na online sprostredkovatel'ské služby pre komerčných použivatel'ov na to, aby sa títo mohli spojit' so spotrebitel'mi. ${ }^{38}$

Internetový vyhl'adávač je chápaný ako digitálna služba umožňujúca vyhl'adávanie webových stránok prostredníctvom kl’účových slov alebo iných údajov. ${ }^{39}$

Nariadenie upravuje požiadavky na obchodné podmienky poskytovatel'ov online sprostredkovatel'ských služieb; podmienky obmedzenia, pozastavenia a ukončenia týchto služieb; povinnost' stanovit' hlavné parametre na určovanie poradia pre poskytovatel'ov online sprostredkovatel'ských služieb, ako aj pre poskytovatel'ov internetových vyhl'adávačov; stanovenie opisu akéhokol'vek rozdielneho zaobchádzania; povinnost' pre poskytovatel'ov zaviest' vnútorný systém vybavovania st’ažností; povinnost' pre poskytovatel'ov určit' mediátorov na mimosúdne riešenie sporov. ${ }^{40}$

Vymáhanie dodržiavania pravidiel stanovených v nariadení sa uskutočňuje:, po prvé, prostredníctvom práva vymedzených subjektov začat' súdne konanie s ciel'om zastavit' alebo zakázat' akékol'vek nedodržiavanie príslušných požiadaviek stanovených v nariadenít ${ }^{41}$; po druhé, prostredníctvom členských štátov, ktoré majú zabezpečit' primerané a účinné presadzovanie nariadenia. ${ }^{42}$

\section{ROZHODOVACIA PRAX}

\subsection{Prípad Facebook}

Príklad ako je možné riešit’ problémy súvisiace s digitálnymi platformami prostredníctvom sút’ažného práva, poskytuje prípad z nemeckého prostredia týkajúci sa platformy Facebook. Facebook je možné vymedzit' ako sociálnu siet', ktorá spája svojich používatel'ov. Tí sa prihlásia prostredníctvom údajov, ktoré podl'a podmienok používania musia byt' pravé. Avšak, v skutočnosti sa osoby často uchyl'ujú k uvádzaniu nepravdi-

\footnotetext{
${ }^{37}$ Článok 2 ods. 2 nariadenia Európskeho parlamentu a Rady (EÚ) 2019/1150 z 20. júna 2019 o podpore spravodlivosti a transparentnosti pre komerčných používatel'ov online sprostredkovatel'ských služieb.

${ }^{38}$ EUROPEAN COMMISSION: Questions and Answers Establishing a Fair, Trusted and Innovation Driven Ecosystem in the Online Platform Economy, s. 10, [online], 2020, [cit. 05. 10. 2020]. Dostupné na internete: https://ec.europa.eu/digital-single-market/en/business-business-trading-practices.

${ }^{39}$ Článok 2 ods. 5 nariadenia Európskeho parlamentu a Rady (EÚ) 2019/1150 z 20. júna 2019 o podpore spravodlivosti a transparentnosti pre komerčných použivatel'ov online sprostredkovatel'ských služieb.

${ }^{40}$ Tamže, články $3-13$.

${ }^{41}$ Tamže, článok 14.

${ }^{42}$ Tamže, článok 15.
} 
vých údajov alebo majú viac ako jeden účet. ${ }^{43} \mathrm{Na}$ svojom profile môžu uviest' d’alšie informácie, ako napríklad školu, ktorú navštevovali, zamestnanie, kde pracujú. Je možné vytvárat' a pridávat' sa do rôznych skupín, ktoré môžu byt' záujmového alebo pracovného charakteru. Na tzv. stenu je možné pridávat' statusy, publikovat' fotografie a videá. Tie sa môžu zverejnit' bud' iba používatel'om, ktorí sú vo facebookovom priatel'stve s daným používatel'om, alebo aj všetkým používatel'om Facebooku. Následne je možné na takéto príspevky reagovat' pomocou ikon, slovne v komentároch, alebo príspevky zdiel'at', čím sa dostanú k širšiemu okruhu l'udí. ${ }^{44}$

Viacerí autori nezostávajú pri vymedzení Facebooku iba ako sociálnej siete. Je možné pozorovat' vývoj tejto platformy od roku 2006, ked' bola charakterizovaná ako miesto stretávania skupiny priatel'ov, kde môžu zdiel'at' informácie; až po platformu, ktorá bola schopná zmenit' svet. ${ }^{45}$ Socioekonomický a politický dosah tejto platformy je predmetom množstva vedecký a odborných článkov. ${ }^{46}$

Konanie na nemeckom sút’ažnom orgáne Bundeskartellamt bolo iniciované ešte v roku 2016, pričom malo íst' o podozrenie zo zneužívania dominantného postavenia týkajúce sa používania údajov o používatel'och tejto sociálnej siete. ${ }^{47}$ Úrad ozrejmil, že podozrieva Facebook z porušovania pravidiel týkajúcich sa ochrany osobných údajov, ktoré môže zároveň byt' zneužitím jeho dominantného postavenia vo forme ukladania neférových podmienok používatel'om Facebooku.

Vyšetrovanie si vyžiadalo niekol'ko rokov. Nemecký sút’ažný orgán vydal rozhodnutie v prípade Facebook vo februári 2019. Rozhodnutie je možné vnímat' ako prelomové a zasluhuje osobitnú pozornost' vo vzt'ahu k viacerým momentom. Po prvé, vymedzenie relevantného trhu je pomerne reštriktívne tak z tovarového, ako aj územného hl'adiska. Jeho definícia sa nakoniec ustálila na relevantnom trhu sociálnych sietí na území Nemecka. Sút’ažný orgán identifikoval rozdiely medzi rôznymi inými poskytovatel'mi služieb, ako sú napríklad LinkedIn, Youtube, Snapchat. ${ }^{48}$

${ }^{43}$ Podl'a podmienok používania Facebooku sa musia uviest' pravidlá pravé údaje a smie sa vytvorit' iba jeden účet. FACEBOOK: Terms of Service, [online], 2019, [cit. 30. 09. 2020]. Dostupné na internete: https:// www.facebook.com/legal/terms.

${ }^{44}$ Ostatné podmienky a pravidlá používania Facebooku sú prístupné na FACEBOOK: Terms of Service, cit. dielo.

${ }^{45}$ GARTENBERG, C. What is Facebook? Just ask Mark Zuckerberg, [online], 2019, [cit. 30. 09. 2020]. Dostupné na internete: https://www.theverge.com/2019/3/8/18255269/facebook-mark-zuckerberg-definition-social-media-network-sharing-privacy.

${ }^{46}$ Napríklad MAZÚR, J. - PATAKYOVÁ, M. T. Regulatory Approaches to Facebook and Other Social Media Platforms: Towards Platforms Design Accountability. Masaryk University Journal of Law and Technology, roč. 13, č. 2, 2019. Dostupné na internete: https://journals.muni.cz/mujlt/article/view/11822.

${ }^{47}$ BUNDESKARTELLAMT. Bundeskartellamt initiates proceeding against Facebook on suspicion of having abused its market power by infringing data protection rules, [online], 2016, [cit. 28. 09. 2020]. Dostupné na internete: https://www.bundeskartellamt.de/SharedDocs/Meldung/EN/Pressemitteilungen/2016/02_03_2016_ Facebook.html

${ }^{48}$ BUNDESKARTELLAMT. Bundeskartellamt prohibits Facebook from combining user data from different sources. Background information on the Bundeskartellamt's Facebook proceeding, [online], 2019, [cit. 28. 09. 2020]. Dostupné na internete: https://www.bundeskartellamt.de/SharedDocs/Publikation/EN/Pressemitteilungen/2019/07_02_2019_Facebook_FAQs.pdf?_blob=publicationFile\&v=6, s. 3 - 4 . 
Pri takto vymedzenom relevantnom trhu nebolo problematické ustálit' dominantné postavenie Facebooku. Sút’ǎnú orgán zistil, že Facebook má až 90 \% podiel na trhu. Navyše, aj keby niektoré aplikácie, ako napríklad WhatsApp alebo Instagram, mohli byt' čiastočne považované za sútažnú protiváhu Facebooku, aj tieto aplikácie patria do skupiny Facebook. ${ }^{49}$ Je potrebné podotknút, že trhová sila nebola posudzovaná iba z hl'adiska podielu na trhu. Nemecký sút’ažný zákon vyžaduje aj posúdenie prístupu k relevantným údajom alebo siet’ovým účinkom vyskytujúcim sa na trhu. Pozícia Facebooku na trhu bola posúdená ako vel'mi silná. Ohl'ad bol braný aj na vysoké bariéry vstupu na tento trh, ako aj absencia tzv. multi-homing-u, t. j. situácie, ked’ by používatel' používal viacero sociálnych sietí naraz. ${ }^{50}$

Zneužitie takto vymedzeného dominantného postavenia bolo identifikované v spôsobe nakladania s údajmi používatel’ov Facebooku. Ako uvádza M. T. Patakyová: „Facebook nielen zbieral dáta svojich použivatel'ov počas toho, ako boli na jeho stránke, ale $k$ zbieraniu dát dochádzalo aj vo vzt’ahu ku stránkam tretích subjektov, ktoré použivali tzv. Facebook Business Tools, čiže napriklad vo vzt'ahu k stránkam, na ktorých bol, Like button'. Problematickou bola aj skutočnost', že Facebook nemal na takéto spracovanie dát skutočne daný súhlas zo strán jeho použivatel'ov."51

Používatelia teda trpeli nie excesívnou cenou za produkt, pretože za prístup k nemu sa neplatí, ale stratou kontroly nad dátami. Nebolo pre nich predvídatel'né, aké dáta sa z akého zdroja skombinujú napríklad na vytvorenie profilu používatel'ov. ${ }^{52}$ Tieto profily slúžia okrem iného na cielenú reklamu, ${ }^{53}$ a teda na zvýšenie príjmov z reklamy pre Facebook.

Zneužitie dominantného postavenia $\mathrm{v}$ tomto prípade úzko súviselo $\mathrm{s}$ porušením ochrany osobných údajov používatel'ov. Je potrebné vnímat' túto súvislost' v kontexte nemeckého sút’ažného práva, pretože samotný nemecký sút’ažný zákon nachádza prepojenie medzi prístupom $\mathrm{k}$ údajom a dominantnou pozíciou na trhu. ${ }^{54}$

Nemecký sút’ažný orgán neuložil Facebooku pokutu, avšak zaviazal ho na zmenu podmienok poskytovania svojich služieb. Facebook mal podl'a rozhodnutia Bundeskartellamt predložit' plán implementácie. Nedodržanie uložených podmienok môže byt' sankcionované pokutou. ${ }^{55}$

${ }^{49}$ Tamže, s. 4.

${ }^{50}$ Tamže, s. $4-5$.

${ }^{51}$ PATAKYOVÁ, M. T. Prišiel čas na rozširenie aplikácie sút’ažného práva? In Zborník príspevkov z medzinárodnej vedeckej konferencie doktorandov a mladých vedeckých pracovníkov 11. 4. - 13. 4. 2019 Míl'niky práva v stredoeurópskom priestore 2019. Bratislava: Univerzita Komenského v Bratislave, Právnická fakulta, 2019, [online], 2019, [cit. 28. 09. 2020]. Dostupné na internete: https:/www.flaw.uniba.sk/fileadmin/praf/ Veda/Konferencie_a_podujatia/milniky_zborniky_2011_2018/Milniky_Zbornik_2019.pdf, s. 602.

${ }^{52}$ BUNDESKARTELLAMT. Bundeskartellamt prohibits Facebook from combining user data from different sources. Background information on the Bundeskartellamt's Facebook proceeding, cit. dielo, s. 5.

${ }^{53}$ MATSAKIS, L. Facebook's Targeted Ads Are More Complex Than It Lets On, [online], 2018, [cit. 01.10.2020]. Dostupné na internete: https://www.wired.com/story/facebooks-targeted-ads-are-more-complex-than-it-lets-on/?mbid=BottomRelatedStories.

${ }^{54}$ BUNDESKARTELLAMT. Bundeskartellamt prohibits Facebook from combining user data from different sources. Background information on the Bundeskartellamt's Facebook proceeding, cit. dielo, s. 7.

${ }^{55}$ Tamže. 
Facebook nebol stotožnený s názorom nemeckého sút’ažného orgánu. Vyšší regionálny súd Düsseldorf vydal predbežné opatrenie a nariadil suspenzívny účinok rozhodnutiu sút’ažného orgánu, pretože samotná žaloba nemá automatický suspenzívny účinok. Düsseldorfský súd nevidel žiadny výsledok zbierania a spracovania údajov Facebookom, ktorý by bol protisút'ažný. Súd okrem iného uviedol, že používatelia Facebooku udelili súhlas na spracovanie osobných údajov, pretože zaklikli, že súhlasia s podmienkami použivania služby. Bolo ich vol'bou, že Facebook chceli používat', a bolo na ich zvážení, či ho používat' chcú za cenu zbierania údajov o nich. Skutočnost', že používatelia Facebooku nepredvídali rozsah spracovania údajov, nemala podl'a súdu súvislost's trhovou silou Facebooku, ale s neprečítaním podmienok. Súd tiež v prípade neidentifikoval žiadnu vylučovaciu praktiku. ${ }^{56}$

Nemecký sút’ažný orgán podal proti rozhodnutiu Düsseldorfského súdu odvolanie na nemecký Federálny súdny dvor. Rozhodnutie odvolacieho súdu z 23. júna 2020 zrušilo rozhodnutie Vyššieho regionálneho súdu Düsseldorf. Podl'a odvolacieho súdu dominantný subjekt musí dat' svojim použivatel'om na výber medzi rôznymi modelmi, inak dochádza k zneužívaniu dominantného postavenia. Ide o požiadavku, ktorá predtým neexistovala a je predzvest’ou markantného významu rozhodnutia Federálneho súdneho dvora. Na druhej strane, Federálny súdny dvor nespája zneužitie dominantného postavenia s porušením právnej povinnosti vyplývajúcej z iného ako sútažného práva, napr. z práva ochrany osobných údajov. Rozhodnutie je signifikantné aj vo vzt'ahu k potvrdeniu ekonomického významu dát. ${ }^{57}$

Prípad Facebook dokumentuje možnost' a reálnost' riešenia problémov digitálnych platforiem prostredníctvom sút’ažného práva. Aj keby bolo sút’ažné právo legislatívne pripravené na identifikáciu trhovej sily z dôvodu prístupu k údajom, stále nastáva problém pri aplikácii konceptu zneužitia dominantného postavenia na digitálne platformy. Nedostatky sút’ažného práva ako regulačného mechanizmu sú viaceré. Zneužitie dominantného postavenia musí byt' rozpoznatel'né v konkrétnej praktike. V prípade Facebooku nemecký sút'ažný orgán identifikoval ako zneuživajúcu praktiku získavania spracovania osobných údajov bez účinne daného súhlasu, v rozpore s reguláciou ochrany osobných údajov. Je možné domnievat' sa, že vel'a iných praktík s potenciálne nebezpečným dosahom na spoločnost' nebude môct' byt' takto identifikované. Navyše, aj keby sa tak stalo, ex post vymáhanie sút'ažného práva nemusí zasiahnut' včas. Je potrebné uvedomit'si, že aj taký fundovaný sút’ažný orgán, ako ten nemecký, analyzoval situáciu od roku 2016 do roku 2019, pričom rozhodnutie stále nie je vyriešené s konečnou platnost'ou na nemeckých súdoch. Rovnako je otázne, či sútažné právo disponuje vhodnými nástrojmi nápravy.

Summa summarum, prípad Facebook akoby dokazoval, že za istých podmienok, ktoré sú do vel'kej miery špecifické pre Nemecko, ${ }^{58}$ je možné problémy prinášané digitálny-

${ }^{56}$ CMS. Victory for Facebook as Düsseldorf court suspends the Bundeskartellamt's decision, [online], 2019, [cit. 01. 10. 2020]. Dostupné na internete: https://www.cms-lawnow.com/ealerts/2019/08/victory-for-facebook-as-duesseldorf-court-suspends-the-bundeskartellamts-decision.

${ }^{57}$ SEELIGER, D. The Facebook decision: is everything clear now? [online], 2020, [cit. 01. 10. 2020]. Dostupné na internete: https://www.d-kart.de/en/blog/2020/06/27/die-facebook-entscheidung-ist-jetzt-alles-klar/

${ }^{58}$ MAZÚR, J. - PATAKYOVÁ, M. T. Regulatory Approaches to Facebook and Other Social Media Platforms: Towards Platforms Design Accountability, cit. dielo, s. 232. 
mi platformami riešit' prostredníctvom sút'ažného práva. Toto riešenie sa však nezdá byt' efektívne a zrejme presahuje aj prirodzený záber sút’ǎného práva.

Rozhodnutie vo veci Facebook je však významné v tom, že aj na európskej úrovni vyvolalo diskusiu o „budúcnosti ochrany hospodárskej sút’aže vo vzt’ahu nielen $k$ samotným internetovým gigantom, ale aj $k$ iným právnym odvetviam ako je ochrana osobných údajov či ochrana spotrebitel'a" 59

\subsection{Prípad Google Shopping}

Pri pojednaní o vhodnosti sút’ažného práva ako regulačného mechanizmu je možné v krátkosti uviest' aj prípad Google Shopping. Rozhodnutie Komisie z júna $2017^{60}$ identifikovalo zneužitie dominantného postavenia spoločnosti Google vo vzt'ahu k službe porovnávania cien. Konkrétne, spoločnost' Google podl'a rozhodnutia Komisie umiestňovala a zobrazovala vlastnú službu porovnávania cien na výhodnejšom mieste. ${ }^{61}$

Spoločnost' Google je nadnárodná technologická spoločnost' založená v Spojených štátoch amerických. Pokrýva viacero sektorov naprieč európskym hospodárskym priestorom. ${ }^{62}$ Najvýznamnejším produktom Google je jeho internetový vyhl'adávač, ktorý umožňuje vyhl'adávanie napríklad prostredníctvom klúčových slov na počítačoch, tabletoch aj smartfónoch. Po zadaní kl'účového slova sa spúšt’a vyhl’adávanie na základe všeobecných aj špeciálnych vyhl'adávacích algoritmov. ${ }^{63}$

Okrem toho Google ponúka aj službu porovnávania produktov. Na základe vyhl'adávania zobrazuje ponuky obchodníkov (z ich webových stránok) a umožňuje ich porovnat'. ${ }^{64}$

Relevantnými produktovými trhmi boli teda trh so všeobecnými vyhl'adávacími službami a trh so službami porovnávania cien. ${ }^{65}$ Dominantné postavenie na prvom spomenutom relevantnom trhu je všeobecne známe a $\mathrm{k}$ jeho existencii prispeli bariéry vstupu na trh a vysoký podiel na trhu. ${ }^{66} \mathrm{~V}$ roku 2016 je podiel vyhl'adávania cez Google na statických zariadeniach viac ako 90 \% v takmer všetkých krajinách EHP. ${ }^{67}$, ,V rozhodnutí sa dospelo $k$ záveru, že spoločnost' Google zneuživa dominantné postavenie na relevantných trhoch so všeobecnými vyhl'adávacími službami v EHP tým, že na svojich stránkach $s$ výsledkami všeobecného vyhl'adávania výhodnejšie umiestňuje a zobrazuje svoju vlastnú službu porovnávania cien v porovnaní s konkurenčnými službami porovnávania

\footnotetext{
${ }^{59}$ MUSIL, A. Německý a evropský přistup k mnohostranným sitovým trhům. In Antitrust, č. 2, 2019, s. 52 .

${ }^{60}$ Rozhodnutie Komisie z 27. júna 2017 týkajúce sa konania podl’a článku 102 Zmluvy o fungovaní Európskej únie a článku 54 Dohody o EHP [Vec AT.39740 - Google Search (Shopping)] [oznámené pod číslom C(2017) 4444].

${ }^{61}$ Tamže, bod 2.

${ }^{62}$ Tamže, bod 4.

${ }^{63}$ Tamže, body $8-12$.

${ }^{64}$ Tamže, bod 26.

${ }^{65}$ Tamže, bod 154.

${ }^{66}$ Tamže, body $264-271$.

${ }^{67}$ Tamže, bod 279.
} 
cien. “68 Je pozoruhodné, že zneužívanie bolo podriadené pod generálnu klauzulu článku 102 ZFEÚ $^{69}$, nie pod článok 102 ods. 2 písm. c) $)^{70}$.

Pokuta, ktorú Európska komisia za toto zneužitie dominantného postavenia udelila, bola 2424495000 eur. $^{71}$

Rozhodnutie je v štádiu prieskumu Všeobecným súdom ako T-612/17 Google a Alphabet proti Komisii. Postavenie Luxemburského súdu v tomuto prípadu bude klúčové, pretože rozhodnutie Komisie bolo kritizované z viacerých strán.

Ako uvádza V. Šmejkal: „Služby Google nie sú oddelené od prehl'adávača do samostatných (dcérskych alebo inak prepojených) podnikov, nemohlo sa teda jednat' o politiku matky nadŕžajúcej vlastným dcéram na úkor ich konkurentov. Hodnota i udržatel'nost' platformy z pohl’adu samotného Google spočíva v to, že na rozvoj služieb poskytovaných uživatel'om zdarma si musi platforma zarobit', čo by pri nepresadzovaní vlastných komerčných služieb bolo st'ažka predstavitelné. Ide o mix vlastný väčsine obchodných modelov internetového podnikania, ktorý spočiva na nalákaní vel'kého množstva uživatel'ov zdarma poskytovanej základnej služby, ktorá je financovaná $z$ výnosov z reklamy a z poskytovania nadväzujúcich služieb (najčastejšie práve sprostredkovanie predaja."72

Je potrebné uviest', že táto kritika je akceptovatel'ná iba čiastočne. Po prvé, nie je možné úplne prehliadat' skutočnost', že použivatelia ,platia“ za službu vyhl'adávača prostredníctvom svojich dát. ${ }^{73}$ Po druhé, je prepájanie produktov vyhl'adávania a porovnávania cien skutočne nevyhnutné pre komerčné prežitie spoločnosti?

V zásade je možné súhlasit' s V. Šmejkalom v tom, daný prípad sa nachádza skôr na kraji ako v centre možností sút’ažného práva. ${ }^{74} \mathrm{~V}$. Šmejkal poukazuje na opomenutie hl'adiska blahobytu spotrebitel'a, problematické vymedzenie relevantných trhov a jednostran-

${ }^{68}$ EURÓPSKA KOMISIA. Zhrnutie rozhodnutia Komisie z 27. júna 2017 týkajúce sa konania podl’a článku 102 Zmluvy o fungovaní Európskej únie a článku 54 Dohody o EHP [Vec AT.39740 - Google Search (Shopping)] [oznámené pod číslom C(2017) 4444], [online], 2017, [cit. 05. 10. 2020]. Dostupné na internete: https://eur-lex.europa.eu/legal-content/SK/TXT/?qid=1516198535804\&uri=CELEX:52018XC0112(01).

${ }^{69}$ Znenie článku 102 ods. 1 ZFEÚ: Akékol’vek zneuživanie dominantného postavenia na vnútornom trhu či jeho podstatnej časti jedným alebo viacerými podnikatel'mi sa zakazuje ako nezlučitel'né s vnútorným trhom, ak sa tým môže ovplyvnit' obchod medzi členskými štátmi.

${ }^{70}$ Znenie článku 102 ods. 2 písm. c) ZFEÚ: Takéto zneužívanie môže zahŕňat’ najmä uplatňovanie nerovnakých podmienok voči obchodným partnerom pri rovnakých plneniach, čím ich v hospodárskej sútaži znevýhodňujú.

${ }_{71}$ Článok 2 rozhodnutia Komisie z 27. júna 2017 týkajúce sa konania podl’a článku 102 Zmluvy o fungovaní Európskej únie a článku 54 Dohody o EHP [Vec AT.39740 - Google Search (Shopping)] [oznámené pod číslom C(2017) 4444].

${ }^{72}$ ŠMEJKAL, V. Rok od rozhodnuti Google Search (Shopping) - ochrana soutěže na trzich online platforem v obtižném hledáni odpovédí na zásadni otázku. In Antitrust, č. 3, 2018, s. 75.

${ }^{73} \mathrm{~K}$ tomu pozri napr. STUCKE, M. E. - GRUNES, A. P. Big Data and Competition Policy. 1st edition. Oxford : Oxford University Press, 2016, p. 57.

${ }^{74}$ Slovami V. Šmejkala jednotlivé prvky rozhodnutia poukazujú „,v úhrne až nápadné dôjdenie na limity možností sútažného práva $k$ tomu, aby sa našlo dostatok argumentov pre sankciu“. ŠMEJKAL, V. Rok od rozhodnutí Google Search (Shopping) - ochrana soutěže na trzích online platforem v obtížném hledání odpovědí na zásadní otázku, cit. dielo, s. 77 . 
ný pohl'ad na (ne)štandardnost' konania podniku. ${ }^{75} \mathrm{Na}$ druhej strane, pod prizmou snahy o zachovanie otvorenej a nemonopolnej štruktúry trhu sa rozhodnutie Komisie javí ako správne a účelné. ${ }^{76}$

Určité napätie medzi potrebou udržat’ inovačnú dynamiku digitálnych trhov s priamym dosahom na spotrebitel'ský blahobyt a potrebou kontrolovat' koncentrovanú trhovú moc a slobodu sút'aže je však z rozhodnutia zrejmé. Podl’a Šmejkala rozhodnutie Komisie môže vyzniet' aj tak, že ide ,proti racionalite podnikania na internete, ktoré nie je udržatel’né bez stálej inovácie vedenej úsilím utiect' konkurencii... "77

\section{ZÁVER}

Vykonaná analýza preukazuje, že úlohou sútažného práva je rovnako chránit' sút’až o trhy, ako aj sútaž na samotných dominantných platformách. Vzhl’adom na dominantnú úlohu dát $\mathrm{v}$ digitálnej ekonómii je potrebné čelit' potláčaniu prístupu $\mathrm{k}$ dátam, prípadne st’aženiu tohto prístupu. ${ }^{78}$ Rizikom pre sút’až však môže byt' aj ,predátorská inovácia“779, pod ktorou sa rozumie ,zmena jedného alebo viacerých technických prvkov s ciel'om obmedzit' alebo vylúčit' sút’až“" ${ }^{80}$ Prostriedky sút’ažného práva by sa však nemali využívat’ na neprirodzenú expanziu do iných, i ked' súvisiacich oblastí, akou je napr. ochrana osobných údajov. Treba súhlasit's D. Geradinom, že ,klúčovou výzvou pre orgány vynucujúce sút’ažné právo je rozlišit protisútažné praktiky, ktoré poškodia spotrebitel'ský blahobyt, od praktik, ktoré síce môžu byt komerčne agresívne, ale stimulujú sút’až a inováciu“ ${ }^{81} \mathrm{~V}$ prípade, ak sút’ažné právo dosahuje svoje limity a jeho aplikácia je bud' t’ažko predstavitel’ná, alebo neefektívna, zdá sa ako vhodné prijatie špecializovanej regulácie vo vzt’ahu k digitálnym platformám.

\section{Literatúra}

BUNDESKARTELLAMT. Bundeskartellamt initiates proceeding against Facebook on suspicion of having abused its market power by infringing data protection rules, [online], 2016, [cit. 28. 09.2 020]. Dostupné na internete: https://www.bundeskartellamt.de/SharedDocs/Meldung/EN/Pressemitteilungen/2016/02_03_2016_ Facebook.html

BUNDESKARTELLAMT. Bundeskartellamt prohibits Facebook from combining user data from different sources. Background information on the Bundeskartellamt's Facebook proceeding, [online], 2019, [cit. 28. 09. 2020]. Dostupné na internete: https://www.bundeskartellamt.de/SharedDocs/Publikation/EN/Pressemitteilungen/2019/07_02_2019_Facebook_FAQs.pdf?_blob=publicationFile\&v=6

${ }^{75}$ ŠMEJKAL, V. Rok od rozhodnutí Google Search (Shopping) - ochrana soutěže na trzích online platforem v obtížném hledání odpovědí na zásadní otázku, cit. dielo, s. 77.

${ }^{76}$ Tamže.

${ }^{77}$ Tamže, s. 76. V tejto súvislosti nie je nezaujímavé ani to, že na rozdiel od Európskej komisie Federálna komisia pre obchod v USA považovala „spôsob, akým Google Search radí výsledky vyhl'adávania, za uživatel'mi vítanú inováciu jeho produktov“. (ŠMEJKAL, V. Rok od rozhodnutí Google Search (Shopping) - ochrana soutěže na trzích online platforem v obtížném hledání odpovědí na zásadní otázku, cit. dielo, s. 71 a literatúra tam citovaná.)

${ }^{78}$ GERADIN, D. What should EU competition policy do to address the concerns raised by Digital Platforms market power?, cit. dielo, s. 7.

${ }^{79}$ Tamže.

${ }^{80}$ Tamže.

${ }^{81}$ Tamže, s. 2. 
CMS: Victory for Facebook as Düsseldorf court suspends the Bundeskartellamt's decision, [online], 2019, [cit. 01. 10. 2020]. Dostupné na internete: https://www.cms-lawnow.com/ealerts/2019/08/victory-for-facebook-as-duesseldorf-court-suspends-the-bundeskartellamts-decision

CRÉMER, J., DE MONTJOYE, Y.-A., SCHWEITZER, H. Competition Policy for the Digital Era, Executive Summary, Luxembourg: Publications Office of the European Union, 2019, [online], [cit. 28. 09. 2020]. Dostupné na internete: https://ec.europa.eu/competition/publications/reports/kd0419345enn.pdf

EUROPEAN COMMISSION. Questions and Answers Establishing a Fair, Trusted and Innovation Driven Ecosystem in the Online Platform Economy, s. 10, [online], 2020, [cit. 05.10.2020]. Dostupné na internete: https:/ec.europa.eu/digital-single-market/en/business-business-trading-practices

FACEBOOK. Terms of Service, [online], 2019, [cit. 30. 09. 2020]. Dostupné na internete: https://www.facebook.com/legal/terms

GARTENBERG, C. What is Facebook? Just ask Mark Zuckerberg, [online], 2019, [cit. 30. 09. 2020]. Dostupné na internete: https://www.theverge.com/2019/3/8/18255269/facebook-mark-zuckerberg-definition-social-media-network-sharing-privacy

GERADIN, D. What should EU competition policy do to address the concerns raised by Digital Platforms market power?, [online], 2018, [cit. 28. 09. 2020]. Dostupné na internete: https://papers.ssrn.com/sol3/ papers.cfm?abstract_id $=3257967$

JONES, A., SUFRIN, B. EU Competition Law. 6th edition. Oxford : Oxford University Press, 2016

KASENČÁKOVÁ, L. Internet ako priestor porušovania pravidiel hospodárskej sút’aže. In Zborník príspevkov z medzinárodnej vedeckej konferencie 21. - 22. októbra 2016, Internet ako priestor možného porušovania práv, Bratislavské právnické fórum 2016. Bratislava : Univerzita Komenského v Bratislave, Právnická fakulta, 2016, s. $58-68$

MATSAKIS, L. Facebook's Targeted Ads Are More Complex Than It Lets On, [online], 2018, [cit. 01.10.2020]. Dostupné na internete: https://www.wired.com/story/facebooks-targeted-ads-are-more-complex-than-it-lets-on/?mbid=BottomRelatedStories

MAZÚR, J., PATAKYOVÁ, M. T. Regulatory Approaches to Facebook and Other Social Media Platforms: Towards Platforms Design Accountability. Masaryk University Journal of Law and Technology, roč. 13, č. 2, 2019. Dostupné na internete: https://journals.muni.cz/mujlt/article/view/11822

MUSIL, A. Německý a evropský přístup k mnohostranným sítovým trhům. In Antitrust, č. 2, 2019, s. 52

Nariadenie Európskeho parlamentu a Rady (EÚ) 2019/1150 z 20. júna 2019 o podpore spravodlivosti a transparentnosti pre komerčných používatel'ov online sprostredkovatel'ských služieb

PATAKYOVÁ, M. T. Prišiel čas na rozšírenie aplikácie sút’ažného práva? In Zborník príspevkov z medzinárodnej vedeckej konferencie doktorandov a mladých vedeckých pracovníkov 11. 4. - 13. 4. 2019. Mílniky práva v stredoeurópskom priestore 2019. Bratislava : Univerzita Komenského v Bratislave, Právnická fakulta, 2019, [online], 2019, [cit. 28. 09. 2020]. Dostupné na internete: https://www.flaw.uniba.sk/filead$\mathrm{min} /$ praf/Veda/Konferencie_a_podujatia/milniky_zborniky_2011_2018/Milniky_Zbornik_2019.pdf

Rozhodnutie Komisie z 27. júna 2017 týkajúce sa konania podl’a článku 102 Zmluvy o fungovaní Európskej únie a článku 54 Dohody o EHP [Vec AT.39740 - Google Search (Shopping)] [oznámené pod číslom C(2017) 4444]

SEELIGER, D. The Facebook decision: is everything clear now? [online], 2020, [cit. 01. 10. 2020]. Dostupné na internete: https:/www.d-kart.de/en/blog/2020/06/27/die-facebook-entscheidung-ist-jetzt-alles-klar/

Smernica Európskeho parlamentu a Rady (EÚ) 2015/1535 z 9. septembra 2015, ktorou sa stanovuje postup pri poskytovaní informácií v oblasti technických predpisov a pravidiel vzt’ahujúcich sa na služby informačnej spoločnosti

STROWEL, A., VERGOTE, W. Digital Platforms: To Regulate or Not To Regulate?, [online], [cit. 28. 09. 2020]. Dostupné na internete: https://ec.europa.eu/information_society/newsroom/image/document/2016-7/uclouvain_et_universit_saint_louis_14044.pdf

STUCKE, M. E., GRUNES, A. P. Big Data and Competition Policy. 1st edition. Oxford : Oxford University Press, 2016

ŠMEJKAL, V. Rok od rozhodnutí Google Search (Shopping) - ochrana soutěže na trzích online platforem v obtížném hledání odpovědí na zásadní otázku. In Antitrust, č. 3, 2018 